\title{
INTRODUCTION TO HERBERT MARCUSE, "ON THE CRITIQUE OF SOCIOLOGY"
}

\author{
David Norman Smith \\ University of Kansas
}

Mid-American Review of Sociology, 1992, Vol XVI, No. 2: 1-13

Critical Theory was bom at a dark moment in world history. The Weimar Republic in Germany had given way to National Socialism, fascism reigned in Italy, and the Bolshevik revolution in Russia had begun its descent into the whirlpool of Stalinism. It became clear that "class consciousness" does not spring fully formed from economic crisis, as many Marxists had imagined, and that socialist democracy is far more difficult to achieve than even its enemies had believed. Nowhere was this more apparent than in Germany, where in 1933 the proudest and strongest labor movement in history fell victim to a grotesquely reactionary regime. Democracy in every form seemed alarmingly fragile, too feeble and embattled to resist the "dictatorship of the corporals" that Max Weber had feared.

This was the context in which the renowned "Frankfurt Institute" began its odyssey from traditional to critical theory. Founded just a decade before Hitler's triumph, the Institut für Sozialforschung had originally been a bastion of Marxist orthodoxy. In July, 1930, however, Max Horkheimer became the second director of the Institute. Under Horkheimer's guidance, the Institute became the source of a new and profoundly original kind of social theory. It is ironic that, in recent years, Critical Theory has come to be regarded as a kind of Olympian culture-critique, resting on the foundation of a fashionably postmodern metaphysic. In its origin, and in the large majority of its endeavors, the Frankfurt Institute was committed to what Horkheimer originally called a "unified," "interdisciplinary" Sozialwissenschaft. For a quarter of a century, Horkheimer and a galaxy of associates - Herbert Marcuse, Erich Fromm, and Theodor Adorno, among others - pursued multidisciplinary research on an expanding scale from the standpoint of a "critical" neo-Marxism. 1 Their goal was to penetrate beneath the surface of society to discern its inner historical tendencies and, if possible, its Achilles' heel. This led them in the direction of a

1. For further data on this multidisciplinary effort, see Dubiel (1985), Kellner (1989), Wiggershaus (1986) and Jay (1973). This research began with an important survey first reported by Erich Fromm in Autorität und Familie (Horkheimer, Ed., 1936). The second great collective work on this theme - The Authoritarian Per-sonality (Adomo et al., 1950) -- is still considered a milestone in the history of social psychology. This is not to say, however, that Critical Theory did not have a 'postmodern' tilt at times. This was evident in Dialectic of Enlightenment (Horkheimer and Adorno, [1944] 1972), and later crystallized in Adorno's Negative Dialectics ([1966] 1973) and Jargon of Auchenticity ([1964] 1973). 

synthetic social theory, in which philosophy and the social sciences were to join
hands.

The first step on this path was an empirical survey of the Weimar proletariat, initiated by Horkheimer and Fromm in 1929. The results were disturbing. It appeared that even many avowed liberals and radicals were susceptible to the blandishments of authoritarian reactionaries. 2 Fascism, it seemed, had roots not only in "material conditions" but in character structure. "For the masses would hardly succumb to the brazen wink of untrue propaganda," as Adorno observed later, "if something within them did not respond to the rhetoric of sacrifice and the dangerous life." 3 The mission of "unified theory" was hence to supplement Marx's critique of political economy with a parallel critique of political psychology: "To be able to come to terms with fascism it was, therefore, considered necessary to complete social theory by psychology, and particularly by analytically oriented social psychology." 4

Hitler's victory forced the Institut into exile, where, in 1934, it became the International Institute of Social Research at Columbia University, in friendly proximity to the sociology department of MacIver and Lynd. Herbert Marcuse, who was the first member of the Institute to settle at Columbia, played a leading role in the ensuing articulation of Critical Theory. In pathbreaking essays on fascism, authority, philosophy, and social theory, Marcuse helped to fashion the unique blend of philosophy and social science that became the Institute's hallmark. Like Horkheimer, who first distinguished between "Traditional and Critical Theory" in 1937 (see Horkheimer [1937] 1972), Marcuse synthesized elements drawn from Hegel, Marx, Weber, and Dilthey. 5 The intent was to produce a "comprehensive theory" in which "the relative truths" of different outlooks and disciplines could be integrated into a unified whole. 6

Ideally, in other words, social theory should be constructive as well as critical. For Max Horkheimer, the "traditional theorists" of orthodox Marxism fell far short of this ideal. Their fatal error, he said, was to assume that class consciousness will be "necessarily generated in the proletariat" when circumstances dictate: 7 In fact, however, class consciousness is inherently

2. For details, see Erich Fromm ([1939] 1984) and Wolfgang Bonss (1984)

3 . Theodor W.. Adorno (1967), p. 68. See Smith (1992) for an elaboration of the logic and implications of this outlook.

4. Ibid., p. 68.

5. Weber and Marx are the main sources of inspiration in Marcuse's essays on fascism ([1934] 1988) and authority ([1936] 1972) and in Horkheimer's "Egoism and the Freedom Movement" ([1936] 1982-83); see also Fromm (1941). Hegel and Dilthey are readily discernible influences in Marcuse's "Philosophy and Critical Theory" ([1937] 1988) and in many other essays by both Horkheimer and Marcuse.

6. Max Horkheimer (1939), p. 324.

7. Max Horkheimer ([1937] 1972), p. 213; emphasis mine. problematic. Under most ordinary circumstances, working people consider capitalist society to be natural and imperishable - and they can turn either left or right under the stress of economic crisis. Marxists who fail to grasp this who serenely await deliverance from the charismatic proletariat - limit themselves to wishful thinking and watchful waiting, faith and irrelevance. Yet this is precisely what traditional theory enshrines as its principle, Horkheimer says. "The intellectual is satisfied to proclaim with reverent admiration the creative strength of the proletariat and finds satisfaction in adapting himself to it and in canonizing it. He fails to see that such an evasion of theoretical effort...and of temporary opposition to the masses (which active theoretical effort on his part might force upon him) only makes the masses blinder and weaker than they need to be."8 Critical theory can play a constructive role, Horkheimer says, by helping tip the scales in favor of "a reasonable organization of society that will meet the needs of the whole community." 9 Theory "...should be a critical, promotive factor in the development of the masses." 10

\section{Critical Theory and Sociology}

Herbert Marcuse had just begun to move in the direction of Critical Theory in this sense when he published "On the Critique of Sociology" in 1931. As recently as 1928, when he had published his first article, Marcuse had advocated a quasi-messianic Marxism of the kind espoused by Georg Lukács in Geschichte und Klassenbewusstein.11 No one had idealized the proletariat with greater apparent sophistication than Lukács, and Marcuse willingly followed in his footsteps. By 1931, however, he had evolved decisively beyond Lukács towards Critical Theory. In a cycle of writings stretching from 1928 until his entry into the Frankfurt Institute in 1932, Marcuse underwent a radical metamorphosis. 12 His first essay, written shortly after the appearance of Martin Heidegger's renowned Sein und Zeit in 1927, was utopian and unsociological, a curious amalgam of Lukács and Heidegger. Not long afterwards, however, Marcuse took a far more subtle stance in a series of little-known essays, including "Zur Kritik der Soziologie," and in a notable but neglected monograph, Hegels Ontologie und die Grundlegung einer Theorie der Geschichlichkeit. 13

Intellectual historians have placed considerable emphasis on Marcuse's early sympathy for Martin Heidegger, with whom he studied at the University of

8. Ibid., p. 214.

9. Ibid., p. 213.

10. Ibid., p. 214.

11. Lukács ([1923] 1971).

12. For details, see the comprehensive bibliography in Kellner (1984).

13. "Zur Kritik der Soziologie" appears here in English for the first time; it first appeared in Die Gesellschaft in 1931. Hegels Ontologie was published in 1932; see the excellent translation by Seyla Benhabib (Marcuse, [1932] 1987). 
Freiburg from 1929-1932. Habermas, for example, calls Marcuse the founder of "Heideggermarxismus," and others claim that he was primarily a Heideggerian existentialist in this period, rather than a Marxist. 14 This is gravely misleading. In reality, Marcuse turned to Heidegger in the hope of finding a philosophical grounding for a specifically Lukácsian view of class consciousness. Sein und Zeit was, in its own way, as utopian as Geschichte und Klassenbewusstein. Seeing a kind of elective affinity between Heidegger's thinking and Lukácsian Marxism, Marcuse sought to unite the two in a grand synthesis.

The influence of Lukacsian themes is especially plain in Marcuse's first essay. 15 Like Lukács, Marcuse was acutely aware that the empirical proletariat is seldom if ever "class conscious" in the ideal-typical sense. But neither Marcuse or Lukács was unwilling to concede that the fate of the working class is strictly circumscribed by its empirical status at any given moment. They believed, on the contrary, that the "mission" of the working class is to function as "...the identical subject-object of history whose praxis will change reality," and that the empirical limits of proletarian consciousness will be transcended as history unfolds. 16 No matter how submissive or conservative the working class might be empirically, its "mission" is to coalesce into a "class for-itself," with emancipation from class rule as its ultimate tendency. 17

This conclusion, as Lukács remarked, "throws an entirely new light on the problem of reality. If, in Hegel's terms, Becoming now appears as the truth of Being, ...then...the developing tendencies of history constitute a higher reality than the empirical 'facts'. "18 This was precisely the point of Marcuse's claim that Marxist theory "culminates in the discovery of historicity (Geschichtlichkeit) as the basic parameter of human existence..." 19 The term "historicity," which figures prominently in Sein und Zeit, was borrowed by

14. See Habermas (1957, p. 230, n. 88). See Morton Schoolman (1980) for the view that Marcuse was a lapsed Marxist in this period. The related claim that he was a Heideggerian is advanced by Alfred Schmidt ([1968] 1988) and Robert Pippin (1988).

15. "Beitrăge zu einer Phănomenolcgie des Historischen Materialismus." This appeared in July 1928 in Philosophische Hefte, pp. 45-68; see the translation, "Contributions to a Phenomenology of Historical Materialism," in Telos 4, 1969.

16. This phrase appears in Lukács ([1923] 1971), p. 197. Similar formulas may be found on pp. 149,189,206, and passim. In a similar vein, Marcuse ([1928] 1969, p. 10) writes that the proletariat will be "the subject of history ... when it grasps and recognizes itself as the object of history..."

17. Marcuse makes this point repeatedly. See, e.g., Marcuse ([1928] 1969), p. 11.

18. Lukács ([1923] 1971), p. 181.

19. Marcuse ([1928] 1969), p. 4.
Heidegger from the philosopher Dilthey, who borrowed it, in turn, from Hegel. Marcuse adapted this concept to argue that the "Becoming" of history is "a higher reality" than its empirical immediacy. Like Heidegger, he rigorously distinguished historical Being and Existence (Sein und Dasein), calling Being the unfolding of necessity, revealed but also hidden by Existence. Adopting Heidegger's category of "thrownness" (Geworfenheit), Marcuse emphasized that Existence is "thrown" before us empirically. But Being, as necessity, is ulterior to Existence. Historicity, the "Being" of history, is thus the ontological ground of "thrown" Existence. This is wholly Heideggerian. But now Marcuse departs sharply from Heidegger to say (á la Lukács) that "historical necessity" is linked to revolution. For Marcuse, unlike Heidegger, Being is the Becoming of social transformation.

Marcuse concludes with a remarkable expression of Lukácsian optimism. Speaking, like Heidegger, of a personified Dasein - in this case, the proletariat - Marcuse concludes that revolution is inevitable. "There is a Dasein whose thrownness consists precisely in overthrowing its own thrownness. Today, historical action is possible only as action of the proletariat, because the proletariat constitutes a Dasein which necessarily contains this action." Such action reveals not only the historicity of the proletariat but the "necessary decadence" of bourgeois society. 20

This argument revealed a rather stunning utopianism, which Marcuse would soon outgrow. His progress was revealed in an article "On the Problem of the Dialectic" (1930-31), in which Marcuse praised the philosopher Siegfried Marck for his balanced approach to Lukács. In Marck's hands, Geschichte und Klassenbewusstein is "scrutinized and appreciated in its essential significance for the development of Marxism, which cannot be overestimated."21 Marck defended Lukács from his mediocre critics, but also "identifies the weak point in Lukács' dialectic: the concept of 'correct class consciousness'. This notion, like the conception of class consciousness in general, is a violation of the dimension of historicity, a structure 'outside' of events from which an artificially abstract connection with history must be produced." 22

By accepting Marck's criticism of Lukács, Marcuse implicitly rejected his own earlier Lukácsianism. He took an additional step away from messianism by conceding that Heidegger, too, was probably an unreliable guide to "history and historicity."23 Yet, instead of discarding the idea of historicity, Marcuse

20. Ibid, p. 33. I've slightly altered the translation.

21. Marcuse ([1930-31] 1976), p. 24. As Kellner points out (1984, p. 388, n. 20), the published translation inverts this point, wrongly saying that the relevance of Geschichte und Klassenbewusstein is "not to be overestimated."

22. Marcuse ([1930-31] 1976), p. 24. I've slightly altered the translation.

23. Ibid., pp. 23-24. 
reaffirms it. In effect, he condemns his earlier approach to historicity as - a violation of the principle of historicity.

Marcuse's conception of this principle had evidently changed. In brief, he seems to have accepted a basically neo-Kantian critique of objectivist Marxism. The ramifications of this point are far-reaching. While studying in Freiburg, Marcuse had pursued a critical analysis of several rival philosophies of history and social science. "The real field of knowledge," he concluded, "is not the given fact about things as they are, but the critical evaluation of them as a prelude to passing beyond their given form. ${ }^{24}$ This opinion led him to repeated criticisms of positivism (especially the logical and sociological positivism of Otto Neurath and the Vienna Circle) and phenomenology (most notably Max Scheler's "material eidetics"). 25 But the neo-Kantianism which reigned in many academic circles was more complex, and Marcuse showed a correspondingly complex attitude towards it. He was especially intrigued by the various forms of neoKantian socialism which emanated from the so-called "Marburg school" and from leading Social Democrats such as Max Adler and Otto Bauer. 26

\section{Autonomy and Necessity}

Inspired by Kant's defense of reason and moral autonomy, the Kantian socialists leveled many serious charges against the shallow "orthodoxy" of Kautsky, Thalheimer, and other Marxist materialists. They argued, most fundamentally, that reason and moral will play a greater role in history than official Marxism concedes. By treating "the subjective factor" as an epiphenomenon of the economy, Marxists fall victim to an objectivist teleology

24. Marcuse ([1941] 1960), p. 145.

25. A Vienna Circle manifesto in 1929 affirmed that "there is knowledge only from experience, which rests on what is immediately given" (Neurath et al., [1929] 1973, p. 11). Marcuse linked this to Husserlian phenomenology: . "Phenomenology is...in principle a descriptive philosophy: it always aims only at describing what is... The theoretical radicalness which seemed audible in [Husserl's] call, 'To the things themselves!' reveals its quietistic, indeed positivist character as phenomenology progresses" ([1936] 1988, pp. 59-60). Scheler's valuetheory was indicted even more sternly, as a form of "receptive heteronomy" in which reason collapses, without residue, into "recognition" (Ibid., p. 63; and cf. p. 44).

26. Hermann Cohen and Paul Natorp were the leading figures of the Marburg school, which also included Rudolf Stammler, Karl Vorländer, and Ernst Cassirer. With the "Baden school" of Rickert and Windelband, the Marburgers formed the core of German neo-Kantianism. Adler and Bauer, both of whom were key figures in Austrian Social Democracy, were well known partisans of neo-Kantian epistemology early in their careers. See Köhne (1991), Willey (1978), van der Linden (1988) and Keck (1975). in which reason and free will are reduced to moments in "a process of natural history." 27 In this teleology, even what Marx called "the leap into the realm of freedom" (the revolutionary transition from capitalism to classless society) is conceived in a determinist fashion, as the "necessary" outcome of an ineluctable objective process. 28 Even revolution is "determined," it seems, by material rather than subjective forces.

Objections to this determinism were expressed with particular insistence by Hermann Cohen and the Marburg school. It is wrong, Cohen wrote, "to represent on the one hand everything as the product of economic forces, while on the other hand moral tasks are seen as fearful apparitions and as post-historical forces that appear as sheet-lightning in the hitherto dark historical sky."29 Rudolf Stammler, voicing "standard criticisms from the neo-Kantian arsenal," said that "the cardinal mistake of the Marxists [is] to interpret the human condition causally," rather than as a realm of subjectivity and autonomy. 30 Moral choice, the neo-Kantians argued, is not bound by the same causal principles that apply to mere objects. The "realm of freedom" must be freely chosen. It is not an inevitable causal fate.

Marcuse first considered this line of reasoning in a series of essays on leading neo-Kantian socialists, including Marck, Max Adler, the renowned "Austro-Marxist" who broke new ground with Kant und der Marxismus (1904), and Marburg philosopher Karl Vorlănder, who was by far the most systematic advocate of a Kantianized Marxism. 31 This is the framework in which Marcuse's commentary on Siegfried Landshut's Kritik der Soziologie becomes most readily intelligible. Landshut's negative judgements of Hegel, Marx, and Weber closely resemble the customary neo-Kantian critique of Marxism. Hegel, we are told, saw people as "instruments manipulated by the Cunning of

27. This is a characterization of Marx's view of history by the Russian economist I. I. Kaufmann, which Marx quoted approvingly in his "Afterword to the Second German Edition" of Capital; see Marx ([1867] 1967), p. 18.

28. Marx's fullest statement about the prospect of a leap to the realm of freedom appears at the end of Vol. 3 of Capital (see Marx [1894] 1981, p. 959).

29. Cohen (1904, p. 38) cited in van der Linden (1988, p. 265). Cohen's reference is to Marx's view that "history" and freedom will only begin in classless society, and that, until then, humanity will subsist in the "prehistory" of heteronomy.

30 . Willey (1978, p. 126), citing Stammler (1921, pp. 23, 56-57).

31 . Vorlander stressed in 1926 that the "'jump into freedom'...cannot be postponed to an undetermined future but must already start in the present..." See Vorländer (1926, p. 348), cited in van der Linden (1988, p. 297). Most of Marcuse's early essays on neo-Kantian socialism are collected in his Schriften, Bd. 1 (1978). 
Reason"; Marx viewed groups and individuals as the "products of...relationships" which are "functional or even causal" in nature; and Weber treated this as the "basic presupposition" of sociological method. This, Landshut says, devalues people and reduces freedom to causality. The altemative is a viewpoint based on "all the categories that originally determined the individual person as human - freedom, happiness," etc. 32

Marcuse felt a very real affinity for Landshut. Both belonged to a small circle of socialists who studied under Heidegger, and both wanted sociological inquiry to probe the "historicity" and "questionability" of capitalist society. 33 But Marcuse felt that Landshut was wrong to say that Hegel and Marx "derived" humanity from the world or reduced reason to causality. In fact, Hegel and Marx had originated a profound new conception of history in which ego and environment are conceived as opposing but indivisible moments in a "dialectic" of change. 34 Landshut failed to grasp precisely this aspect of "transformation," which Marcuse calls "the proper category of historicity ...discovered and grasped by Marx on the ground worked by Hegel..."35 Eager to deny that humanity is "derived" from the world, Landshut re-creates the very "disjunction" of humanity and world for which he had blamed Hegel and Marx - by overstating the independence of personality. Landshut's concept of "historicity" is too one-sided, Marcuse says, to balance subject and object. His Kritik der Soziologie is, in the end, too Kantian. 36

32. See "On the Critique of Sociology," below, for a fuller report of Landshut's views. For Landshut, Marx was the key figure in this drama, the proponent of the "sharpest form" of the causal "derivation" of humanity from the world.

33. See Katz (1982), pp. 66, 76. Landshut won a permanent place in the annals of Marxology by editing Marx's early writings (Marx, 1932). He later edited Alexis de Tocqueville and analyzed Jewish culture and society (see, e.g., Landshut 1950).

34 . In Hegels Ontologie Marcuse anticipated the work of Merold Westphal (1990). Both say that Hegel's Phenomenology of Spirit ([1807] 1977) is a deeply historical work which is subverted at the end by Hegel's reversion to the ideal of the tran-scendental knowing subject. Hegel's Science of Logic ([1812] 1969) is similarly divided, Marcuse says, between a valid exposition of the forms of "historicity" typical of "being," "essence" and "life" and a disappointing conclusion which returns Hegel to the idée fixe of an absolute epistemological ego.

35. Marcuse hesitated to use the word "dialectic," which often served more as a dogmatic slogan than as a conceptual aid (see Marcuse ([1930-31] 1976). In Hegels Ontologie, he thus argues entirely in terms of historicity.

36. Kant, of course, tended to derive the world from the subject. Marcuse feels that Landshut leans too far in this direction in his zeal to oppose objectivism.
Marcuse prefers to view humanity and the world through the prism of a wider, more integrated conception of "historicity" which he defines in the rather obscure language of "motility" (Bewegtheit), "unfolding" (Geschehen), etc. It should be noted, first, that these are technical terms, drawn from Marcuse's reading of Hegel's Logic, 37 as explained in Hegels Ontologie. This study contains a wealth of close reasoning on "the fundamental character of historical happening." 38 The main premise is that "what happens" in history "happens" in a unique sense. "Historicity is what defines history and thus distinguishes it from 'nature' or the 'economy'," Marcuse writes. Historicity signifies the meaning we intend when we say of something that it is 'historical'."39 The nexus between historicity and Geschehen (happening or unfolding) and Bewegtheit (motility) "is suggested by the very word 'history' (Geschichte). What is historical (geschi-chtlich), happens (geschicht) in a certain manner. History will be our concern as a process of happening and a form of motility." 40

This premise, of course, is purely formal, and can never be a substitute for concrete historical study. 41 As Marcuse later noted vis-à-vis Sartre, "strictly philosophical analysis...abstracts from the historical factors which constitute empirical concreteness." 42 Such "meta-historical" analysis flees before "the invasion of real history," which involves "the action and reaction of specific social groups under specific historical conditions": manual workers, entrepreneurs, sales clerks, writers, and others. 43 Yet Marcuse does not retreat from the view that there are typical forms of movement in history. In his magnum opus, Reason and Revolution, he still seeks to pierce the surface of events, to discern the underlying logic of change. Like Marx, he "regards every

37 . Marcuse offers a new approach to the Logic which, he says ([1932] 1987, p. 325), has few precedents. Among older authors, he cites Trendelenberg. The most noteworthy recent contribution, he says, is a study by Emst Manheim (1930). For Manheim's insights into Critical Theory, see the present issue of this journal.

38. This is a phrase from a postcard cited by Benhabib, $(1987$, p. xii).

39. Marcuse (1932), p. 1.

40. Ibid., p. 1. Compare Heidegger, whose translators write: "'Geschichte'... stands for the kind of 'history' that actually happens" (as opposed to 'Historie', which refers to written history). Being and Time ([1927] 1962), p. 30 , n. 1.

41. Marcuse felt that phenomenology and existentialism gave in to this temptation. In lieu of the abstract knowing subject they had placed "an equally abstract 'his-toricity'," falling short of the goal set by Dilthey.when he urged research into historicity as a means of probing the "real life process" ([1936] 1988, p. 78).

42. Marcuse (1948), p. 161.

43 . Marcuse (1948), pp. 189, 175. 
historically developed social form as in fluid movement, and therefore takes into account its transient nature not less than its momentary existence..." 44

The originality and lasting value of Critical Theory is that it takes both sides of the dialectic seriously. Autonomy and necessity, historical movement and the empirical present, change and "the given" - all merit attention. Although, at the beginning of his literary career, Marcuse believed that people are carried along by waves of historical necessity, he soon realized that history, unlike nature, is a realm in which freedom and causality play interwoven parts. "There can be no blind necessity," as he wrote in 1941, "in tendencies that terminate in a free and self-conscious society." 45

Marcuse shared this insight with neo-Kantian socialists like Vorlănder. But, unlike the "rather dry" neo-Kantians, 46 Marcuse and his fellow critical theorists recognized that the "autonomy" of the human spirit cannot simply be affirmed, but is, in fact, problematic. Whether an individual or a classe is more or less "free" at any given moment is an empirical question which is not susceptible to a priori deduction. Under the pressure of social relations in the family or elsewhere, conduct may become "compulsive" in a way that removes it from the realm of autonomy in the pure sense. Authoritarians, for example, who yield to paranoid delusions or compulsions, are plainly not "free" in a pure sense. Yet it would be wrong to conclude that freedom is impossible, a chimera. It was precisely the genius of the Frankfurt School to make this an empirical and historical question. In no other intellectual tradition has the human potential for self-determination been scrutinized with equal care. From Autorität und Familie to Reason and Revolution and The Authoritarian Personality, the Critical Theorists made freedom and democracy their paramount concerns. They translated philosophical theorems into a research agenda - reaping a rich harves of questions, data, methods, and insights. Marcuse's early reflections were a step on this path.

44. Marx ([1867] 1967, p. 20).

45. Marcuse ([1941] 1960), p. 318. For an elaboration of this point, see the excellent book by Marcuse's widow, the late Erica Sherover-Marcuse (1986).

46. This is Marcuse's apt designation of the neo-Kantianism of his day, as reported in his interview with Frederick Olafson ([1977] 1988), p. 96.

\section{REFERENCES} Adorno, Theodor W. [1964] 1973. The Jargon of Authenticity. Evanston:
Northwestem University Press.

[1966] 1973. Negative Dialectics. London: Routledge \& Kegan Paul.

1967. "Sociology and Psychology," in New Left Review, 46 (November-December).

and associates. 1950. The Authoritarian Personality. New York: Harper \& Brothers. Benhabib, Seyla. 1987. "Translator's Introduction," in Herbert Marcuse ([1932]
1987).

Bonss, Wolfgang. 1984. "Critical Theory and Empirical Social Research: Some Observations," in Erich Fromm (1984), pp. 1-40.

Cohen, Hermann. 1904. Ethik des reinen Willens. Berlin: Bruno Cassirer.

Fromm, Erich. 1985. Theory and Politics. Cambridge, MA: MIT Press. Germany.Ch. [1939] 1984. The Working Class in Weimar 1941. Eambridge, MA: Harvard University Press.

Habermas, Jürgen. 1957. "Zur philom. New York: Holt, Rinehart and Winston. Marxismus, "in Philosophische Rusische Diskussion um Marx und den Rundschau, 5 (3/4).

Hegel, G. W. F. Antworten auf Marcuse. Frankfurt: Suhrkamp.

Press.
P. [1807] 1977. Phenomenology of Spirit. Oxford: Clarendon

Heidegger, Martin. [1927] 1962 1969. Hegel's Science of Logic. London: Allen \& Unwin.

Horkheimer, Max. [1936] 1982-83 "Being and Time. New York: Harper \& Row. Telos 54, Winter.

Alcan. [19.

Critical Theory. New York: Seabury, pp. 188-243...." in Horkheimer, 1939 "Teabury, pp. 188-243.

Sozialforschung, VIII (3).

New York: Seabury.

Jay, Martin. 1973. The Dial

Jay, Martin. 1973. The Dialectical Imagination. Boston: Little, Brown.

Biography. 1982. Herbert Marcuse and the Art of Liberation: An Intellectual

University of Wisconsin.
Unimothy Raymond. 1975. Kant and Socialism. Ph.D. dissertation,

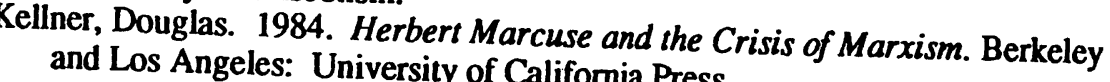
and Los Angeles: University of California Press. Johns Hopkins University Press. 
Kohnke, Klaus Christian. 1991. The Rise of Neo-Kantianism. Cambridge: Cambridge University Press.

Landshut, Siegfried. 1950. Jewish Communities in the Muslim Countries of the Middle East. London: Jewish Chronicle.

Lukács, Georg. [1923] 1971. History and Class Consciousness. Cambridge, MA: The MIT Press.

Manheim, Emst. 1930. Zur logik des konkreten Begriffs. Munich: Beck.

Marcuse, Herbert. [1928] 1969. "Contributions to a Phenomenology of Historical Materialism," in Telos 4, pp. 3-34.

$12-39$

- 1932. Hegels Ontologie und die Grundlegung einer Theorie der Geschichlichkeit. Frankfurt: V. Klosterman Verlag. [1932] 1987. Hegel's Ontology and the Theory of Historicity. Cambridge, MA, and London: The MIT Press.

[1934] 1988. "The Struggle Against Liberalism in the Totalitarian view of the State," in Marcuse (1988), pp. 3-42

155.

1972. "A Study on Authority," in Marcuse, (1972), pp. 51-

. [1936] 1988. "On the Concept of Essence," in Marcuse (1988), pp. 43-87.

[1937] 1988. "Philosophy and Critical Theory," in Marcuse (1988), pp. 134-158.

- [1941] 1960. Reason and Revolution: Hegel and the Rise of Social Theory. Boston: Beacon Press.

. [1948] 1972. "Sartre's Existentialism," in Marcuse (1972), pp. 159. 190.

1972. Studies in Critical Philosophy. Boston: Beacon Press.

1978. Schriften, Bd. 1. Frankfurt: Suhrkamp.

1988. Negations: Essays in Critical Theory. London: Free Association Books.

Marx, Karl. [1867] 1967. Capital, Vol. 1. New York: International.

[1894] 1981. Capital, Vol. 3. New York: Vintage.

1932. Der Historische Materialismus: die Frühschriften. Leipzig: A Kröner, edited by Siegfried Landshut and J. P. Mayer.

Neurath, Otto, Hans Hahn and Rudolf Carnap. [1929] 1973. "The Scientific Conception of the World: The Vienna Circle," in M. Neurath and R. S. Cohen, Eds. Empiricism and Sociology. Dordrecht: Reidel, pp. 299-318.

Olafson, Frederick.. [1977] 1988. "Heidegger's Politics: An Interview with Herbert Marcuse," in Pippin, Feenberg, and Webel, 1988.

Pippin, Robert B. 1988. "Marcuse on Hegel and Historicity," in Pippin, Feenberg, and Webel, 1988.

Pippin, Robert B., Andrew Feenberg and Charles Webel. 1988. Marcuse: Critical Theory and the Promise of Utopia. South Hadley, Massachusetts: Bergin \& Garvey.

12
Schmidt, Alfred. [1968] 1988. "Existential Ontology and Historical Materialism in the Work of Herbert Marcuse," in Pippin, Feenberg, and
Webel, 1988.

Schmidt, Alfred and Herbert Marcuse, Eds. 1973. Existentialistische MarxInterpretation. Frankfurt: Europaische Verlaganstalt, 1973.

Schoolman, Morton. 1980. The Imaginary Witness: The Critical Theory of Herbert Marcuse. London: Collier Macmillan.

Sherover-Marcuse, Erica. 1986. Emancipation and Consciousness .Oxford and New York: Basil Blackwell.

Smith, David Norman. 1992. "The Beloved Dictator: Adorno, Horkeimer, and the Critique of Domination," in Ben Agger, Ed., Current Perspectives in Social Theory. Stammler, Rudolf. 1921. Die materialistische Geschichtsauffassung.
Gutersloh: E. Bartelsmann.

Van der Linden, Harry. 1988. Kantian Ethics and Socialism. Indianapolis and Cambridge: Hackett.

Vorlander, Karl. 1926. Kant und Marx. Tübingen: J. C. B. Mohr. This is the second, revised edition of a study first published in 1911 .

Westphal, Merold. 1990. History and Truth in Hegel's Phenomenology. New Jersey and London: Humanities Press. First printed in 1979.

Wiggershaus, Rolf. 1986. Die Frankfurter Schule. Munich: Hanser.

Willey, Thomas E. 1978. Back to Kant. Detroit: Wayne State University Press. 